\title{
CONSIDERAÇÕES CRÍTICAS SOBRE O SUBSTANCIALISMO E O PROCEDIMENTALISMO E SUA RELAÇÃO COM A DEMOCRACIA NO CONTEXTO DA FILOSOFIA POLÍTICA CONTEMPORÂNEA
}

\author{
Cristina Foroni Consani
}

UFRN

\begin{abstract}
Resumo: Este artigo apresenta considerações críticas a respeito das concepções substacialista e procedimentalista da democracia e da atuação do poder judiciário na relação entre direitos fundamentais e o princípio da soberania popular. As críticas apontam para os problemas que podem advir, para as práticas democráticas, quando temas de grande relevância política passam a ser decididos em arenas não representativas e sem a possibilidade de interferência dos cidadãos. $O$ propósito geral do texto é repensar o espaço da política nas sociedades democráticas contemporâneas.
\end{abstract}

Palavras-chave: Substancialismo; procedimentalismo; democracia; direitos fundamentais.

\begin{abstract}
This paper presents critical assessments about substantive and procedural conceptions of democracy, as well as analyzes the role of judicial review in protecting fundamental rights and democratic process. These critical considerations indicate problems that may arise when highly relevant political issues are decided in unrepresentative arenas and without the citzens' interference. The general purpose of the text is to rethink the space of politics in contemporary democratic societies.
\end{abstract}

Keywords: Substantive democracy; procedural democracy; judicial review; fundamental rights.

\section{Introdução}

Substancialismo e procedimentalismo são termos que se referem a dois aspectos da relação entre direito e política, ou entre direitos fundamentais e soberania popular. Trata-se, primeiramente, de um modo de compreender a democracia, isto é, segundo a definição substancial, a democracia tem uma substância, um conteúdo e não se reduz a procedimentos para a tomada de decisões políticas. Por outro lado, uma definição procedimental define a democracia pelos procedimentos que regem a prática política, tais como eleições periódicas, regras que estabelecem quem pode votar e ser votado, regras que regulam os processos de decisão, deliberação, entre outras. Mas a discussão contemporânea acerca do substancialismo e do procedimentalismo não envolve apenas o modo pelo qual a democracia é definida. Abarca também o papel dos poderes do Estado, notadamente do poder judiciário, no momento de resolver conflitos entre direitos fundamentais e decisões 
coletivas. Nesse sentido, há aqueles que defendem ser papel do judiciário fiscalizar apenas as regras do jogo democrático, isto é, apenas os procedimentos, e deixar que o conteúdo de questões polêmicas sobre direitos (por exemplo, aborto, eutanásia, casamento gay) seja decidido no processo político (procedimentalismo). Por outro lado, há também o entendimento de que se a democracia não pode ser definida apenas por regras que regulam as práticas democráticas, mas também pela proteção a um conjunto de direitos básicos, nesse caso o papel do judiciário é cuidar para que esses direitos não sejam violados pelas decisões coletivas (substancialismo).

Trata-se de uma discussão contemporânea, mas cujas raízes se encontram na modernidade e que pode ser estudada a partir dos textos de filosofia e teoria política da época das revoluções liberais, especialmente da Revolução Americana e da Revolução Francesa. A relação tensa entre os direitos básicos protegidos por declarações de direitos e o ideal de soberania popular é um tema central nas obras de autores como Jefferson, Paine, Madison, Sieyès e Condorcet. Talvez a melhor expressão desse conflito em textos modernos seja o clássico debate entre Jefferson e Madison, no qual o primeiro levanta a tese de que "a terra pertence aos vivos" e, por essa razão, cada geração possui o direito de modificar sua constituição, enquanto o segundo recusa tal proposta justamente por temer a instabilidade política e a insegurança jurídica que podem dela resultar (cf. JEFFERSON, 1977, p. 445451; MADISON, 1790).

Hodiernamente alguns autores têm entendido ser possível a elaboração de uma resposta capaz de conciliar os dois ideais em questão. Desde os anos de 1960, quando Hayek considerou que a constituição é um mecanismo que permite o "apelo do povo bêbado ao povo sóbrio" (HAYEK, 2011 , p. 268), a ideia do pré-compromisso constitucional tem sido utilizada para indicar a harmonização entre esses dois ideais. No final dos anos de 1970 e durante as duas décadas seguintes a ideia de pré-compromisso voltou ao centro do debate da filosofia política e constitucional com a comparação que se estabeleceu entre o pré-compromisso e o mito de Ulisses, retomado de Spinoza por Jon Elster (cf. ELSTER, 1989) e também por Stephen Holmes (HOLMES, 1988, p. 195-240). A narrativa do herói que, consciente de sua falibilidade diante do canto das sereias, mas querendo ouvir a melodia, ordena à sua tripulação que o ate ao mastro de seu navio para não sucumbir quando perder a lucidez, aproxima-se do ideal defendido pelo constitucionalismo, qual seja, o de uma limitação auto-imposta. Segundo Elster, "a estratégia de Ulisses consiste em comprometer as gerações posteriores estabelecendo uma constituição que inclua cláusulas que lhes impeçam de alterá-la facilmente". (ELSTER, 1989, p. 160) Holmes, ao analisar essa estratégia, reforça seu caráter de autolimitação para afirmar que a tensão entre constituição e democracia, reconhecida por autores modernos como Jefferson e Madison, na realidade não existe, pois a constituição é uma limitação colocada pelo povo sobre si 
mesmo, cujas restrições são necessárias para assegurar o exercício da liberdade (dos antigos) e das liberdades (dos modernos).

Assim, a constituição é um mecanismo não apenas que limita o poder, mas que também o cria e organiza as regras de seu funcionamento. $\mathrm{O}$ estabelecimento de um rol de temas inatingíveis pelas decisões populares, como os direitos e garantias fundamentais, é necessário para proteger o próprio processo de participação política. O que torna o pré-compromisso constitucional compatível com o autogoverno é a precisão das instruções (procedimentos e direitos) acordadas, as quais tornarão seu intérprete um mero instrumento da vontade racional que as instituiu, assim como a tripulação de Ulisses o foi.

Não obstante as tentativas de conciliação, a discussão contemporânea continua longe de alcançar um consenso a respeito de como lidar com a relação entre direitos fundamentais e o princípio da soberania popular. Em algumas propostas o problema é enfrentado simplesmente deslocando o local da política para o campo do direito, ou, para dentro das cortes constitucionais, as quais passam a figurar como intérpretes da vontade do povo. Desse modo, o que está em disputa nessa questão não é apenas o papel dos tribunais, mas também o conceito de democracia e o espaço da política.

Nesse texto, pretende-se analisar a tensão entre direitos fundamentais e democracia a partir do debate entre substancialistas e procedimentalistas. Isso será feito em dois momentos: na primeira seção, serão apresentados os principais argumentos do em debate; na segunda seção serão apresentadas algumas críticas formuladas contra ambas as concepções a partir de estudos de Jeremy Waldron e de Richard Bellamy, as quais se propõem justamente repensar o espaço da política nas sociedades democráticas contemporâneas. Cabe aqui ressaltar que o objetivo deste texto não é fazer uma exegese de passagens específicas das teorias e autores estudados, mas sim realizar uma avaliação crítica das propostas apresentadas e verificar em que medida essa discussão lança luz sobre problemas relevantes enfrentados pela filosofia política contemporânea.

\section{Os argumentos substancialista e procedimentalista}

A leitura da democracia em uma perspectiva substancial ou substancialista parte do pressuposto de que a democracia assume certos valores morais, em especial que cada cidadão merece igual consideração e respeito como possuidores de direitos autônomos. Assim, uma constituição é necessária para assegurar que até mesmo leis feitas democraticamente irão aderir a estes valores morais. A visão substancialista está amplamente focada no papel e justificação de uma Declaração de Direitos (ou dispositivos constitucionais que protegem os direitos individuais) sustentada pelo controle de constitucionalidade das leis. 
Um dos principais defensores desta tese é o jusfilósofo Ronald Dworkin. Ao analisar a relação entre constituição e democracia Dworkin é um dos autores que sustenta não haver nenhum conflito entre ambos os ideais. Ele defende esta posição com base em dois principais argumentos, a saber: primeiro, ele adota uma concepção de democracia distinta da democracia majoritária, o que o permite defender, em segundo lugar, que a constituição e os direitos fundamentais por ela incorporados são passíveis de interpretação por meio de uma leitura moral, a qual pode ser realizada tanto pelo povo e seus representantes quanto pelo poder judiciário, embora ele considere o último o fórum mais adequado para a interpretação constitucional (cf. DWORKIN, 2006b, p. 18).

A conciliação entre os ideais do constitucionalismo (direitos) e democracia (autogoverno do povo) é feita por Dworkin a partir da rejeição da concepção majoritária de democracia e da opção por uma concepção à qual ele chama de coparticipativa (partnership). Segundo o autor, a concepção majoritária de democracia defende que o povo governa a si mesmo quando o maior número de pessoas possui o poder político fundamental. Neste sentido, as leis e as diretrizes políticas de uma determinada comunidade seriam aquelas preferidas pelo maior número de pessoas. O problema desta concepção, segundo ele, é que ela define a democracia apenas procedimentalmente, deixando desprotegidos direitos e garantias fundamentais dos cidadãos (cf. DWORKIN, 2011, p. 383/384).

A concepção coparticipativa de democracia, por outro lado, sustenta que o autogoverno não é simplesmente o governo pela maioria do povo exercendo sua autoridade sobre todos, mas o governo pelo povo como um todo agindo como associados (partners). O povo somente pode ser entendido como uma comunidade (partnership) se aceitar que precisa agir com igual respeito e consideração por todos os outros associados. Admite-se, assim, que uma maioria política tenha autoridade moral para decidir sobre questões controversas, mas somente se as instituições por meio das quais ela governa forem suficientemente legítimas. A legitimidade neste caso é definida pelo respeito e segurança oferecidos pelas instituições governamentais à dignidade humana e aos seus princípios ${ }^{1}$ (cf. DWORKIN, 2011, p. 322).

De acordo com uma concepção comunitária, para saber se a democracia prevalece em um país deve ser perguntado o que suas leis dizem e não quem, como e quando estas leis são feitas. As leis básicas devem prevenir o uso opressivo do poder do Estado, assim como discriminações legais arbitrárias, devem respeitar a liberdade de pensamento, de expressão, de

\footnotetext{
1 Os princípios políticos da dignidade humana, segundo Dworkin, são os seguintes: a) o valor intrínseco da vida humana, segundo o qual toda vida humana tem uma espécie de valor objetivo; b) a responsabilidade pessoal, de acordo com a qual cada pessoa é responsável pela realização do sucesso de sua própria vida (princípio que suporta os direitos liberais tradicionais como liberdade de expressão, consciência, atividade política, religião, etc). Cf. DWORKIN, 2006a, p. 09/10)
} 
associação e devem, ainda, assegurar a independência moral e intelectual de cada cidadão. Desse modo, Dworkin entende que o conflito entre direitos individuais e autogoverno do povo não ocorre, pois a liberdade depende da relação entre o governo e todo o conjunto de cidadãos considerados em sua coletividade e não do governo e cada indivíduo. Por isso, a liberdade positiva é aquela que vigora quando o povo controla aqueles que governam, e não o contrário; e é esta liberdade que se afirma quando se impede que a maioria faça valer a sua vontade (cf. DWORKIN, 2006b, p. 32/33).

A partir da definição da democracia como uma concepção coparticipativa, segundo a qual o respeito e a preservação de direitos e liberdades individuais são colocados como um limite ao autogoverno popular, Dworkin sustenta que a melhor forma de interpretar a constituição é por meio de uma leitura moral. Ele parte do pressuposto que em um ordenamento jurídico não existem apenas regras claras, mas também princípios que podem ser demasiadamente abstratos (cf. DWORKIN, 2006b, p. 02). Tal abstração abre espaço para que essas normas, no momento da aplicação, sejam interpretadas. A interpretação, entretanto, deve se dar com base numa leitura moral da Constituição, realizada de forma construtiva e restringida tanto pela história quanto pelo ideal político da integridade. Por um lado, o recurso à história faz com que o intérprete busque entender o que os autores da Constituição quiserem dizer. ${ }^{2}$ Por outro lado, o ideal político da integridade é compreendido como um princípio por meio do qual é possível cobrar do Estado e das instituições políticas e jurídicas uma ação coerente pautada em normas e princípios (DWORKIN, 2003, p. 200).

Dessa forma, não há nada necessariamente antidemocrático em permitir que um país seja governado, em parte, por juízes interpretando as leis básicas, pois o objetivo da democracia, no nível da lei básica, não é somente proclamar como leis os princípios de direitos abstratos, mas também conseguir que sua interpretação reflita o direito, ou a melhor concepção do regime democrático. O coeficiente democrático de uma constituição deve, dentro dessa proposta, ser analisado a partir de seu conteúdo e não do procedimento utilizado para criar o conteúdo.

$2 \mathrm{O}$ autor chama a atenção para o uso que a interpretação constitucional por meio de uma leitura moral faz da história, que é bastante distinto da interpretação originalista. Segundo ele, a leitura moral insiste que a constituição significa o que seus autores quiseram dizer, ao passo que uma leitura originalista insiste que a constituição significa o que seus autores queriam que sua linguagem fizesse, assim, os direitos fundamentais não devem ser interpretados como princípios morais abstratos, mas como referencias aos pressupostos e expectativas que os próprios autores tinham acerca da correta aplicação daqueles princípios. Como exemplo ele cita a interpretação que foi dada ao princípio da igualdade de status contido na Décima Quarta Emenda no julgamento do caso Brown vs. Board of Education, no qual a segregação racial nas escolas foi considerada inconstitucional. Segundo ele, essa interpretação realizou uma leitura moral de um princípio constitucional. Uma leitura originalista ratificaria a segregação sob o fundamento de que os autores do dispositivo de igual proteção não acreditavam que a segregação escolar era uma negação da igualdade de status. Cf. DWORKIN, 2006b, 19/20. 
Dworkin aposta que um judiciário independente é capaz, pela justa construção e efetivação da lei constitucional, de cumprir seguramente certas condições racionais para a identificação do indivíduo com sua agência legislativa ou com sua comunidade política. A interpretação constitucional das normas é considerada pelo autor um modo superior de deliberação republicana (cf. DWORKIN, 2006b, p. 47).

Em suma, Dworkin nega que haja tensão entre os ideais da constituição e aqueles da democracia e afirma que os direitos e liberdades fundamentais são condição sine qua non para a autodeterminação popular. Em outras palavras, ele reconhece que o conteúdo (substância) da constituição é um limite democraticamente eleito para a soberania popular manifestada por meio de decisões majoritárias. Portanto, entende não haver nenhum conflito entre eles.

A concepção procedimental ou procedimentalista da democracia questiona a defesa feita por autores como Dworkin de que os direitos e liberdades fundamentais devem ser retirados da deliberação democrática. Para o procedimentalismo, desde que os procedimentos para a tomada de decisões democráticas estejam abertos para todos os cidadãos e para todos os pontos de vista e, ainda, desde que as minorias estejam devidamente representadas, não há nada de antidemocrático em permitir que se decida por meio dos procedimentos democráticos questões controversas sobre direitos. Contudo, essa leitura também coloca o poder judiciário no centro da vida política do Estado ao atribuir a essa instituição o papel de avaliar e proteger os procedimentos democráticos. Os argumentos procedimentalistas serão aqui apresentados a partir da obra de Habermas. ${ }^{3}$

Habermas figura entre os teóricos que admitem que as cortes inevitavelmente empregam julgamentos substantivos ao trabalharem nos processos, mas sustentam que elas também evitam impor sua própria visão substantiva do que a política deveria ser. A relação entre democracia e direito é o principal tema de Faktizität und Geltung, publicado por Habermas em 1992. ${ }^{4}$ Nesse texto, o filósofo alemão dedica-se à elaboração de um modelo procedimental do direito e da política e, para tanto, enfrenta questões tais como a fundamentação legítima do direito a partir de sua gênese no processo democrático e a relação entre os poderes do Estado, o que o leva a entrar na discussão a respeito da legitimidade das cortes constitucionais para exercer o controle de constitucionalidade. Serão retomados desse texto de Habermas apenas dois pontos que são relevantes para o tema ora abordado, a saber, a

\footnotetext{
3 Para outras propostas que também apresentam argumentos em prol de um modelo procedimental de democracia e de jurisdição constitucional ver, por exemplo, John Hart Ely - Democracy and Distrust: A Theory of Judicial Review (cf. ELY, 1980) e Robert Post - Constitutional Domains:Democracy, Community, Management (POST, 1995).

4 Texto traduzido para o português sob o título Direito e Democracia: entre facticidade e validade.Tradução de Flávio Beno Sieveneichler, (Volumes I e II) Rio de Janeiro: Tempo Brasileiro, 1997. Doravante será utilizada a tradução brasileira.
} 
reconstrução do direito, reconciliando a autonomia privada com a autonomia pública por meio da teoria do discurso e o papel atribuído ao tribunal constitucional.

Habermas sustenta que essa tensão entre direitos fundamentais e democracia, ou entre autonomia privada e autonomia pública, pode ser solucionada a partir da aplicação do Princípio do Discurso ao processo jurídico de normatização.

Segundo esse princípio "são válidas as normas de ação às quais todos os possíveis atingidos poderiam dar o seu assentimento, na qualidade de participantes de discursos racionais." (HABERMAS, 1997, I, p. 142)5. O Princípio do Discurso, cujo conteúdo é normativo, fundamenta-se "nas condições simétricas de reconhecimento de formas de vida estruturadas comunicativamente", ou seja, Habermas parte do pressuposto de que "questões práticas em geral podem ser julgadas imparcialmente e decididas racionalmente.” (HABERMAS, 1997, I, p. 143/144) Esse princípio aplica-se a dois campos: a moral e ao direito.

A aplicação do Princípio do Discurso ao direito se dá por meio do Princípio da Democracia, segundo o qual "somente podem pretender validade legítima as leis jurídicas capazes de encontrar o assentimento de todos os parceiros do direito, num processo jurídico de normatização discursiva." (HABERMAS, 1997, I, p. 145) Este princípio tem duas finalidades: criar o sistema de direitos e estabelecer a "linguagem que permite à comunidade entender-se enquanto associação voluntária de membros do direito iguais e livres" (HABERMAS, 1997, I, p. 146). É a partir do entrelaçamento entre os princípios do discurso e da democracia com a forma jurídica que Habermas sustenta sua tese de que a autonomia privada e a autonomia pública são cooriginárias.

O sistema de direitos deve conter, de modo abstrato, direitos imprescindíveis para que os cidadãos participem do processo democrático em igualdade de condições. Primeiramente assegura-se a autonomia privada a partir de três categorias de direitos, quais sejam: a) direitos a iguais liberdades subjetivas de ação; b) direitos que garantam o status de um membro igual e autônomo da comunidade jurídica; c) direitos que afirmem a possibilidade de postulação judicial. ${ }^{6} \mathrm{Em}$ segundo lugar, assegura-se a autonomia pública

50 autor traz definições dos termos empregados na formulação desse princípio: "O predicado 'válidas' refere-se a normas de ação e a proposições normativas gerais correspondentes; ele expressa um sentido não específico de validade normativa, ainda indiferente em relação à distinção entre moralidade e legitimidade. Eu entendo por 'normas de ação' expectativas de comportamento generalizadas temporal, social e objetivamente. Para mim, 'atingido' é todo aquele cujos interesses serão afetados pelas prováveis consequências provocadas pela regulamentação de uma prática geral através de normas. E 'discurso racional' é toda a tentativa de entendimento sobre pretensões de validade problemáticas, na medida em que ele se realiza sob condições da comunicação que permitem 0 movimento livre de temas e contribuições, informações e argumentos no interior de um espaço público constituído através de obrigações ilocucionárias."

${ }^{6}$ Habermas adverte 0 leitor que os direitos constantes dessas três primeiras categorias ainda não 
conferindo-se (d) direitos de igual participação em processos de formação da opinião e da vontade e de criação do direito legítimo. Por fim, os direitos de autonomia privada e pública implicam (e) "direitos fundamentais a condições de vida garantidas social, técnica e ecologicamente, na medida em que isso for necessário para um aproveitamento" (HABERMAS, 1997, I, p. 159/160), em condições iguais dos direitos elencados acima.

Sendo esses direitos elencados de forma abstrata, é o processo democrático que irá estabelecer seu conteúdo. O modo pelo qual os cidadãos participarão desse processo de criação do direito legítimo é detalhado por Habermas quando ele delineia o seu modelo normativo de democracia, denominado política deliberativa, o qual é estruturado como uma proposta intermediária entre o modelo liberal e o republicano, ambos refutados, em parte, pelo autor.

A concepção habermasiana de política deliberativa estabelece condições que o procedimento ideal de tomada de decisão e deliberação tem que respeitar, sendo estas desenvolvidas de forma dual ou bidimensional. $\mathrm{O}$ caráter dual da política deliberativa reside na conceituação de espera pública, que é dividida pelo autor em esfera pública parlamentar e esfera pública geral. Desta forma, as deliberações devem acontecer dentro de uma esfera pública parlamentar, mas têm como pauta temas advindos de uma esfera pública geral, "da qual é titular o público de cidadãos em geral" (HABERMAS, 1997, II, p. 32). A esfera pública geral caracteriza-se por sua "estrutura anárquica", que mesmo estando sujeita aos efeitos da repressão e exclusão do poder social distribuído desigualmente e a distorções que podem surgir nos processos comunicativos, ainda assim tem a vantagem de ser um meio de comunicação livre de limitações e eficaz para captar novas necessidades e problemas, colocando-os sob perspectiva, para que possam ser posteriormente inseridos na agenda parlamentar (cf. HABERMAS, 1997, II, p. 33). Esses temas oriundos do fluxo comunicacional da esfera pública geral serão, então, dentro da esfera pública parlamentar, transformados em leis através de deliberações e, desta forma, atingem o poder administrativo aplicado à sociedade.

Resta saber como Habermas enfrenta uma das questões mais delicadas para a filosofia constitucional contemporânea, a saber, a do papel atribuído ao tribunal constitucional nas sociedades democráticas. Segundo o filósofo alemão, essa questão precisa ser analisada dentro da divisão de poderes entre as instituições do Estado. Ele enfatiza que sob a ótica da teoria do discurso cada uma das funções, executiva, legislativa e judicial, é diferenciada segundo as formas de comunicação e argumentos que lhes competem. Assim sendo, as leis criadas por meio de um procedimento

podem ser entendidos como direitos liberais que protegem os cidadãos contra o Estado, haja vista eles serem colocados em um momento anterior à organização jurídica de um poder estatal. Eles regulam apenas as relações entre civis livremente associados e estabelecem direitos e obrigações recíprocas. Cf. HABERMAS, 1997, I, p. 159. 
democrático legítimo (função legislativa) fundam "uma proteção do direito garantido por tribunais independentes" (função judicial) e "subtraem da administração implementadora" (função executiva) o tipo de argumentos normativos portadores das resoluções legislativas e das decisões judiciais (cf. HABERMAS, 1997, I, p. 238) ${ }^{7}$

Nesse sentido, o autor ressalta que quando se trata da fundamentação de normas, apenas "o legislador político tem o poder ilimitado de lançar mão de argumentos normativos." Os tribunais não podem "dispor arbitrariamente dos argumentos enfeixados nas normas legais", mas com certeza farão uso desses argumentos na aplicação do discurso jurídico a casos concretos, haja vista terem que manter a coerência do sistema jurídico em seu todo. Quanto à função executiva, Habermas considera que, diferentemente de legisladores e juízes, não cabe ao administrador construir nem reconstruir argumentos normativos, pois "as normas sugeridas amarram a persecução de fins coletivos a premissas estabelecidas e limitam a atividade administrativa no horizonte da racionalidade pragmática." (HABERMAS, 1997, I, p. 239)

As atribuições do tribunal constitucional, então, são delineadas dentro desse esquema institucional e, segundo Habermas, consistem em "proteger o sistema de direitos que possibilita a autonomia privada e pública dos cidadãos." (HABERMAS, 1997, I, p. 326). O autor é categórico ao afirmar que compete aos legisladores, por meio do processo democrático, fazer uso de argumentos normativos para a fundamentação de leis, ou seja, cabe ao processo deliberativo realizado na esfera pública formal atribuir conteúdo normativo ao direito. O papel do tribunal é proteger os procedimentos por meio dos quais o direito legítimo é formado. Nesse aspecto, Habermas parece buscar um modelo de jurisdição constitucional que seja ao mesmo tempo atuante na proteção de direitos sem se imiscuir demasiadamente na política. $O$ tribunal constitucional, diz ele, "não pode assumir o papel de um regente que entra no lugar de um sucessor menor de idade. Sob os olhares críticos de uma esfera pública jurídica politizada - da cidadania que se transformou na 'comunidade dos intérpretes da constituição' - o tribunal constitucional pode assumir, no melhor dos casos, o papel de um tutor" (HABERMAS, 1997, I, p. 347).

A proposta de Habermas e sua tentativa de conciliar direitos individuais e soberania popular, permite pensar a Constituição de modo procedimental, como uma estrutura política que contém princípios normativos gerais que, por um lado, sustentam as condições do jogo democrático e, por outro lado, insistem que se determinadas categorias de direitos não forem respeitadas, não pode nem mesmo haver espaço para a democracia e a formação livre da opinião e da vontade.

Dentro do arranjo institucional habermasiano, tanto o poder judiciário quanto o executivo possuem funções bastante restritas. O judiciário

\footnotetext{
7 Itálico no original.
} 
limita-se a proteger o sistema de direitos que possibilita a autonomia privada e pública dos cidadãos. $\mathrm{O}$ executivo é um mero administrador, que deve estar atado à persecução de fins coletivos. Logo, a instituição com maior autonomia é o legislativo, que deve atuar segundo as orientações advindas da esfera pública informal. O controle do poder político se realiza tanto por meio do clássico mecanismo da separação dos poderes, e também, em certa medida, pelos cidadãos que podem influenciar a formação da vontade parlamentar.

\section{Críticas ao substancialismo e ao procedimentalismo}

As teorias estudadas até agora enfrentam o problema da tensão entre soberania popular e direitos fundamentais na democracia constitucional. Cada uma delas, ao seu modo, considera ter superado essa tensão. Alguns teóricos, contudo, têm apontado para o fracasso dessas teorias ao tentar reconciliar os ideais em questão. Sustentam que ao final todos os argumentos apresentados para este debate atribuem às cortes constitucionais o papel de guardiãs dos valores morais (substancialismo) ou dos procedimentos democráticos (procedimentalismo), assegurados por meio de uma constituição.

Sendo assim, a relação entre constituição e democracia coloca em lados opostos o poder legislativo e as cortes constitucionais, o que obrigaria a tomada de uma posição em favor de uma ou de outra instituição e, consequentemente, em favor da preponderância de um dos ideais em questão.

Entre os autores que endossam esse tipo de crítica, são destacados aqui os posicionamentos de Jeremy Waldron e de Richard Bellamy. Ambos se posicionam nesse embate a favor da soberania popular e, por conseguinte, tendem a fortalecer o legislativo representativo e a tecer severas críticas a um modelo de controle de constitucionalidade considerado forte, isto é, que autoriza a invalidação de leis aprovadas pelo poder legislativo representativo. Em grande medida, as críticas de Waldron e de Bellamy recaem sobre a relação entre constituição e democracia estabelecida por autores como Dworkin que, ao retirar do debate democrático um determinado conjunto de direitos, permite que esses mesmos direitos sejam interpretados dentro das cortes constitucionais.

Contudo, endossam as críticas feitas ao procedimentalismo segundo as quais as considerações sobre os procedimentos democráticos são também valores que informam as visões sobre resultados substantivos e, por essa razão, também deveriam estar abertos para a deliberação democrática (cf. WALDRON, 1993, p. 39/40; BELLAMY, 2007, p. 110/111).

Com relação ao procedimentalismo, como tem sido reiteradamente apontado por seus críticos, defensores ou não da tese dos valores fundamentais, os limites dessa leitura são encontrados em suas contradições internas. Ela tem que lidar com o fato de que não se pode julgar se o processo é justo sem uma visão do que conta como um resultado justo e não se pode julgar um resultado 
justo sem uma referência a algum enfoque de valores fundamentais. De fato, participação e procedimentos tornam-se valores cujo significado está ao desacordo popular como qualquer outra coisa na política. As pessoas discordam sobre como os direitos de participação deveriam ser entendidos e como eles deveriam ser equilibrados com outros valores (visões a respeito dos limites constitucionais, representação proporcional, frequência das eleições, fundação dos partidos, a relação entre a liberdade de expressão e propaganda política, a necessidade de referendos, etc.). ${ }^{8}$

Consequentemente, a distinção entre o enfoque substancialista e procedimentalista do controle de constitucionalidade colapsa, haja vista que em ambos a corte constitucional tomará o lugar do povo no momento da tomada de uma decisão sobre valores. E valores (conteúdo e forma da lei), no entendimento dos críticos, precisam ser interpretados naquilo que Waldron chama de "circunstâncias da política", ou seja, circunstâncias nas quais os membros de um certo grupo precisam buscar "uma estrutura comum ou decisão ou modo de ação sobre determinado assunto, mesmo diante do desacordo a respeito do que essa estrutura, decisão ou ação deveria ser." (WALDRON, 1999, p. 100-102) Por essa razão, qualquer espécie de précompromisso constitucional é recusado pelos autores.

Os argumentos apresentados por Waldron e por Bellamy expõem de forma bastante detalhada os problemas em torno da relação entre direitos fundamentais e o princípio da soberania popular, assim como os problemas que podem advir da atuação robusta e constante do poder judiciário na decisão de questões eminentemente políticas. A definição de democracia que permeia a obra desses autores pode ser considerada uma versão da democracia majoritária, com preponderância do poder legislativo representativo. Serão apresentadas, a seguir, as críticas de Waldron e de Bellamy, respectivamente.

Ao analisar a democracia a partir da perspectiva do pré-compromisso constitucional, Waldron apresenta duas objeções a esse modelo. A primeira objeção reporta-se ao desacordo político. $\mathrm{O}$ autor considera que existe uma grande diferença entre o pré-compromisso individual, ao qual fazem menção as narrativas de Ulisses e do bêbado, e o pré-compromisso coletivo (propriamente o que seria o modelo de auto-limitação por meio de uma constituição). Em uma sociedade, mesmo em momentos de "lucidez" há desacordos a respeito de como os direitos são concebidos, pesados e relacionados a outros valores. E, o que está presente não é uma embriaguez, mas sim incertezas genuínas e mudanças de opinião. Segundo o autor, a metáfora ideal seria a do caso teológico (uma pessoa dividida entre crenças religiosas distintas opta por uma fé fundamentalista e entrega a chave de sua biblioteca pessoal - na qual existem livros sobre diversas crenças - a um

\footnotetext{
${ }^{8}$ Além das obras já citadas de Waldron e de Bellamy, essas críticas também podem ser encontradas nos seguintes textos: DWORKIN, 2000, p. 80-92; HABERMAS,1997, I, p. 328/329; TRIBE, 1980, p. 10631080.
} 
amigo, pedindo que a chave jamais the seja devolvida; algum tempo depois a pessoa quer voltar à sua biblioteca e solicita ao amigo a devolução da chave). Com base nesse exemplo, o autor procura monstrar que as opiniões sobre decisões relevantes mudam ao longo do tempo. Assim, os temas divergentes devem ser submetidos ao debate atual (cf. WALDRON, 1993, p. 48; WALDRON, 1998, p. 284).

A segunda objeção sustenta a incompatibilidade do pré-compromisso com um julgamento independente. No exemplo de Ulisses ou do bêbado, o julgamento caberia mais à tripulação do barco e ao amigo do que àqueles que se auto-regularam, ou seja, é um julgamento externo. Dessa forma, as restrições não operariam mecanicamente, mas seriam aplicadas por uma pessoa ou por um grupo de pessoas com poder de decisão (como as cortes constitucionais). Consequentemente, as decisões podem ser contrárias às intenções iniciais do agente que as instituiu. Ou seja, ao se avaliar a democracia constitucional segundo o modelo do pré-compromisso, permite-se que os julgamentos sobre as normas em questão (conteúdo ou forma) sejam feitos pelo tribunal constitucional. Waldron discorda que esta seja a melhor forma de uma sociedade democrática se regular e, levando em conta essas objeções, apresenta críticas ao que considera uma versão forte do controle de constitucionalidade. As objeções acima expostas mostram, em sua opinião, que não há razão para se supor que os direitos estão melhor protegidos pelo controle de constitucionalidade das leis pelo judiciário do que por legislativos democráticos.

Waldron enfrenta o problema do protagonismo judicial em muitos dos seus textos, mas aqui será abordado principalmente um ensaio de 2006 denominado The Core of the Case Against Judicial Review, no qual o autor faz claramente a distinção entre controle de constitucionalidade em sentido forte (que ele rejeita) e em sentido fraco (que ele aceita).

O controle de constitucionalidade em sentido forte é definido como aquele em que: a) as cortes possuem autoridade para não aplicar um estatuto a um caso particular ou para modificá-lo (na sua aplicação) a fim de adequá-lo aos direitos individuais; b) as cortes possuem autoridade para deixar de aplicar um estatuto; c) ou ainda, as cortes possuem autoridade para invalidar leis em sua totalidade ou em parte (cf. WALDRON, 2006, p. 1354).

Contra o controle de constitucionalidade em sentido forte, Waldron busca identificar um argumento central independente das manifestações históricas e dos efeitos que tais decisões produzem. Aqui ele reporta-se diretamente à afirmação de Dworkin em O Império do Direito, segundo a qual "os Estados Unidos são uma sociedade mais justa do que teriam sido se seus direitos constitucionais tivessem sido confiados à consciência de instituições majoritárias." (DWORKIN, 2003, p. 426) É exatamente contra a possibilidade de averiguação da relação (necessária) entre controle de constitucionalidade e justiça que se voltam as críticas de Waldron. Segundo ele, essa é uma questão mal colocada. O quanto o controle de constitucionalidade é capaz de tornar 
uma sociedade mais justa é algo de difícil verificação, pois se decisões como a de Brown vs. Board of Education ${ }^{9}$ foram capazes de promover a igualdade racial e combater a segregação, por outro lado, durante a denominada "Lochner era", entre 1885 e 1930, cortes norte-americanas estaduais e federais revogaram aproximadamente 150 partes de leis que protegiam as relações e condições de trabalho tais como salário mínimo, proibição de trabalho infantil entre outras (cf. WALDRON, 1999, p. 288). Assim, exemplos de justiça e de injustiça podem facilmente ser encontrados na jurisprudência de cortes constitucionais. Por essa razão, a defesa do controle de constitucionalidade não pode ser feita apenas sob o argumento da justiça. Para Waldron, o que se deve verificar é a relação existente entre controle de constitucionalidade e democracia, ou melhor, a compatibilidade entre ambos.

A partir dessa perspectiva, o controle de constitucionalidade em sentido forte é considerado vulnerável em dois pontos: em primeiro lugar, não é o meio adequado para uma sociedade avaliar direitos sobre os quais discorda; em segundo lugar, é politicamente ilegítimo, pois é uma decisão majoritária de um pequeno número de ofíciais não eleitos, logo, fere o princípio da representação e da igualdade política (cf. WALDRON, 2006, p. 1351). Waldron sustenta que do fato do poder de interpretação e revisão pelo judiciário ser inevitável não se pode inferir que outras instituições não possam também ter o poder de revisar entendimentos oficiais sobre direitos. O autor acredita ser um grande erro considerar que os direitos que os juízes estão interpretando e revisando são colocados além do alcance da reinterpretação e revisão democrática. Ele acredita que a questão é a seguinte: ou uma sociedade assume a necessidade de emendas constitucionais ou não e, uma vez consideradas necessárias, as emendas devem ser feitas por instituições representativas democráticas (cf. WALDRON, 1993, p. 42).

Se um povo considera desejável que uma Declaração de Direitos seja tratada como um "organismo vivo" capaz de adaptação a novas condições, então tem que enfrentar a questão da autoridade: quem deve ter poder para participar nesse processo orgânico cotidiano. Pois se é necessário a uma sociedade adaptar cânones do direito a situações não previstas pelo poder constituinte, é difícil ver por que o povo (atual) e seus representantes deveriam ser excluídos desse processo (cf. WALDRON, 1993, p. 43).

Por fim, Waldron considera que o argumento mais insidioso em prol do judiciário é aquele que aponta para as imperfeições da democracia, pois esse argumento busca tirar o poder de cidadãos ordinários sobre questões de mais alta importância política e moral (cf. WALDRON, 1993, p. 45). Desse modo, ao invés de se falar sobre dificuldades contra-majoritárias, dever-se-ia distinguir entre cortes decidindo por voto majoritário e cidadãos ordinários

9 Decisão da Suprema Corte norte-americana de 1954. Declarou a inconstitucionalidade de leis estaduais que estabeleciam a segregação racial nas escolas públicas. Cf. Brown v. Board of Education 347 US 483 (1954). 
decidindo por voto majoritário pois, ao final, é também desse modo que são decididos casos controversos dentro dos tribunais constitucionais. Então, a questão é quem consegue participar, e não como se decide em caso de desacordo" (porque a resposta para como, é sempre, por maioria).

Contudo, Waldron admite a prática do controle de constitucionalidade em sentido fraco, o qual dar-se-ia nos seguintes termos: as cortes podem inspecionar a legislação a respeito de sua conformidade com os direitos individuais, mas os juízes não podem deixar de aplicá-la ou moderar sua aplicação simplesmente porque de outro modo direitos seriam violados; esse modelo confere aos juízes pouca autoridade; um clássico exemplo é o Reino Unido onde as cortes podem revisar a legislação e declarar a incompatibilidade com os direitos individuais, mas não podem invalidá-la (cf. WALDRON, 2006, p. 1355).

De acordo com Waldron, o controle de constitucionalidade em sentido fraco é pressuposto para uma democracia constitucional que não escamoteia a política e, ela pode sustentar-se em qualquer sociedade na qual estejam presentes as seguintes condições: a) instituições democráticas em ordem razoável de bom funcionamento incluindo um legislativo representativo eleito na base do sufrágio universal; b) um conjunto de instituições judiciais em boa ordem de funcionamento escolhidas de forma não representativa para ouvir reivindicações individuais e assegurar o governo da lei; c) o comprometimento da maior parte dos membros da sociedade e de seus oficiais com os direitos individuais e das minorias; d) um desacordo substancial, de boa fé e persistente sobre direitos (cf. WALDRON, 2006, p. 1355).

Para Waldron, o controle de constitucionalidade em sentido forte impede que o desacordo sobre direitos seja confrontado diretamente, pois ele é sempre colocado como uma questão de interpretação. Além disso, tratar a autoridade judicial como a principal base para o reforço constitucional deixa a constitucionalidade do próprio poder judiciário sem controle externo. Conectado a isso há o perigo de que o controle de constitucionalidade possa facilmente tornar-se uma forma de elaboração da lei pelo judiciário (cf. WALDRON, 2009, p. 278). Assim, segundo o autor, o controle de constitucionalidade em sentido forte é incompatível com a democracia.

Bellamy chega a conclusões bastante semelhantes. Em um texto de 2007 denominado "Political Constitutionalism: A republican defense of the constitutionality of democracy" (BELLAMY, 2007, p. 04), ele estabelece uma distinção entre constitucionalismo legal (aquele que se pauta no controle de constitucionalidade para promover a defesa de direitos) e constitucionalismo político (comprometido com os ideais democráticos da igualdade de consideração e respeito entre cidadãos e com a crença em que os processos democráticos são mais legítimos e eficazes para resolver desacordos sobre direitos).

Bellamy questiona a legitimidade e a efetividade das cortes constitucionais para deliberar e julgar desacordos sobre direitos e sua objeção 
central ao controle de constitucionalidade é que essa prática despe o povo de seu mais básico direito constitucional: o poder de direcionar novamente qualquer questão e decidir em conjunto como lidar com ela. Negando ao povo este poder e autorizando, ao invés disso, um grupo de juízes que não é controlado pelo povo, o constitucionalismo legal estabelece um regime de dominação em que quase todos são sujeitos a regras arbitrárias dos outros, nomeadamente, de juízes de uma corte constitucional. De acordo com Bellamy, tal prática promove uma espécie de erosão da democracia, ou, em termos republicanos, uma espécie de dominação injusta pelas cortes. Essa é considerada a falha fundamental do constitucionalismo legal.

Muitas das objeções apresentadas por Waldron ao controle de constitucionalidade em sentido forte são corroboradas por Bellamy. Contudo, ele é ainda mais incisivo do que Waldron com relação ao papel das cortes e reavalia a atuação do judiciário inserindo-o em um novo desenho de equilíbrio de poderes. De acordo com Bellamy, as decisões tomadas por órgãos judiciais tendem a ter muitos dos vícios atribuídos aos processos democráticos. O autor acredita ser problemático, por exemplo, afirmar que as cortes decidem somente com base em princípios morais e argumentos racionais e, por essa razão, estão isentas da interferência de auto-interesse ou de preconceito. Ao contrário, ele afirma que a cortes "fazem parte do sistema político e da cultura política de forma geral. É impossível e inapropriado isolá-las da influencia política." (BELLAMY, 2007, p. 38/39).

Do mesmo modo, em seu entendimento não se sustenta o argumento segundo o qual decisões judiciais podem produzir maior segurança jurídica do que os parlamentos porque estão limitadas pela lei e pelos próprios precedentes judiciais. Segundo ele, é mais fácil para uma corte constitucional mudar seu entendimento a respeito de uma determinada matéria do que para um parlamento aprovar uma emenda constitucional (cf. BELLAMY, 2007, p. 36). Além do mais, assim como Waldron, Bellamy chama a atenção para o fato de que também nas cortes constitucionais as decisões ocorrem por votação majoritária só que, no caso dos tribunais, a representatividade da sociedade fica comprometida principalmente porque não são raros os casos em que as decisões são tomadas com um único voto de diferença (cf. BELLAMY, 2007, p. $37 / 38)$.

Bellamy questiona até mesmo a efetividade do controle de constitucionalidade em casos nos quais o desacordo social é muito forte. Como exemplo, ele evoca o julgamento de Brown vs. Board of Education para mostrar que a vitória por meios legais dificilmente põe fim a uma disputa, a menos que a decisão judicial tenha amplo suporte político. A decisão da Suprema Corte norte-americana que considerou inconstitucional leis estabelecendo a segregação racial nas escolas públicas ocorreu em 1954. Contudo, o autor ressalta que as mudanças sociais passaram mesmo a acontecer dez anos após essa decisão, em razão da atuação contínua do 
movimento em prol dos direitos civis e da aprovação, pelo Congresso, do Civil Rights Act $(1964)^{10}$ e do Voting Rights Act (1965) ${ }^{11}$.

Não obstante sua pouca eficácia social na ausência de sustentação política, o autor ainda argumenta que os casos tratados pelas cortes, ainda que versem sobre direitos individuais, criam políticas públicas (cf. BELLAMY, 2007, p. 30). Essas escolhas determinam, em grande medida, os padrões e características do desenvolvimento de uma sociedade e estruturam o comportamento dos indivíduos e, desse modo, fazem um julgamento sobre o bem-comum da comunidade. Sendo assim, o autor defende que esse tipo de julgamento é melhor realizado pelo legislativo do que pelo judiciário, precisamente porque a coletividade é ali representada.

Bellamy, assim como Waldron, traz o exemplo da Inglaterra, da Nova Zelândia e da Austrália para fazer referência a sociedades nas quais as cortes não podem declarar a inconstitucionalidade da legislação aprovada pelo Parlamento, podem apenas declará-la incompatível com os direitos fundamentais e encaminhá-la para reavaliação do próprio Parlamento.

O constitucionalismo norte-americano é contraposto ao modelo da commonwealth, no qual ele considera que a tensão entre democracia e constitucionalismo é superada por meio do diálogo travado entre cortes e parlamentos (cf. BELLAMY, 2007, p. 47/48). ${ }^{12}$

$\mathrm{O}$ autor retoma do neorrepublicanismo, principalmente de Philip Pettit, o ideal de liberdade como não-dominação e aplica-o ao constitucionalismo. Desse modo, considera que quando a deliberação sobre direitos em desacordo ocorre dentro das cortes constitucionais, os cidadãos não são tratados com igual consideração e respeito porque seu direito de participar da discussão e de decidir é retirado. Logo, isso gera dominação. ${ }^{13} \mathrm{O}$ constitucionalismo político evitaria a dominação retirando das cortes constitucionais o poder de declarar a inconstitucionalidade da legislação ordinária, promovendo o processo de discussão pública dos direitos e substituindo a tradicional separação de poderes por um equilíbrio de poderes. $\mathrm{O}$ equilíbrio aqui invocado por Bellamy é ressaltado justamente por uma

\footnotetext{
${ }^{10}$ Lei Federal que proibiu as a discriminação racial, incluindo qualquer forma de segregação.

${ }^{11}$ Lei Federal que vedou práticas eleitorais discriminatórias.

12 Bellamy (e também Waldron) contrapõe aqui o modelo norte-americano (no qual o poder judiciário tem a atribuição de revisar e invalidar a legislação aprovada pelo poder legislativo, do mesmo modo como no modelo brasileiro) e o modelo da Commonwealth (no qual o poder judiciário não tem a possibilidade de invalidar uma lei considerada contrária aos direitos fundamentais).

13 Bellamy estabelece uma distinção entre opressão e dominação: "A opressão envolve danos aos interesses individuais através de formas de interferência direta ou indireta como exploração, violência ou marginalização; a dominação é uma forma de interferência arbitrária e, desse modo, 0 indivíduo que sofre algum tipo de dominação é injustiçado em seus próprios direitos. Aqueles que são dominados são tratados como súditos, ou seja, falta a eles uma das fontes básicas para ser tratado como igual, para ter um direito igual de fala. A presença de dominação adiciona ao resultado opressão. A dominação faz opressão. Assim, não somente a dominação é perniciosa em si mesma, mas também, como temos visto, frequentemente a opressão tem sua origem na dominação." Cf. BELLAMY, 2007, p. 152-154.
} 
instituição não representativa e não responsável politicamente não ter a prerrogativa de invalidar leis aprovadas por uma instituição representativa e responsável politicamente (o poder legislativo).

Bellamy propõe uma divisão horizontal do poder, a qual pode ser alcançada por arranjos que compartilham as funções executiva e legislativa entre grupos competitivos. Uma divisão horizontal do poder político suportaria um enfoque procedimental de argumentação pública, assegurando direitos e o governo da lei mais do que a noção tradicional da separação dos poderes (cf. BELLAMY, 2007, p. 196 e ss.). O aspecto-chave desse mecanismo de equilíbrio de poder é a clássica estratégia republicana da competição entre governantes. A competição, nesse caso, teria a função de promover a inclusão por meio de incentivos à construção de uma ampla coalizão de apoiadores e institucionalizaria a contestação (cf. BELLAMY, 2007, p. 230).

Em suma, as teses acima apresentadas recusam o controle de constitucionalidade em sentido forte como modo adequado de proteger e deliberar sobre direitos em conflito. Enquanto Waldron considera o controle de constitucionalidade em sentido forte antidemocrático, Bellamy vai ainda mais além e o entende como uma forma de dominação. Segundo esses autores seria mais adequado que os direitos fundamentais fossem protegidos e interpretados por meio de processos democráticos envolvendo a participação dos cidadãos. A supremacia legislativa surge como consequência desse posicionamento. Todavia, resta saber como é delineado o controle do legislativo dentro desta proposta de que o tribunal constitucional pode sugerir alterações na legislação aprovada pelo legislativo quando identificar alguma violação à constituição, mas não pode decidir pela inconstitucionalidade da lei. Vale lembrar que em uma democracia constitucional, a ideia de qualquer poder sem controle também é antidemocrática. Esse parece ser o ponto fraco das teses sustentadas por Waldron e Bellamy.

\section{Considerações finais}

Neste artigo foram apresentadas teorias que buscam equacionar a tensão existente entre os ideais da constituição (direitos fundamentais) e da democracia (soberania popular), assim como as críticas tecidas a estas propostas conciliatórias.

Na proposta substancialista a democracia é definida não apenas pelos procedimentos de participação e organização política, mas também por um conjunto de direitos básicos ou fundamentais. Tal definição da democracia permite conferir ao poder judiciário a função primordial de proteger tais direitos caso ameaçados ou violados pelo processo político. À luz das práticas democráticas, o problema dessa proposta é que o debate político acaba por ser colocado sob o jugo de um tribunal constitucional. 
A proposta procedimentalista tenta superar esse problema deixando que divergências a respeito de valores substantivos sejam interpretadas, avaliadas e pesadas pela representação popular no poder legislativo, deixando ao tribunal constitucional a atribuição de fiscalizar e assegurar o processo democrático. O modelo habermasiano de democracia procedimental, como visto, tenta conciliar a proteção aos direitos fundamentais e à democracia. Dentro dessa proposta, é bastante coerente o papel atribuído pelo autor ao tribunal constitucional, qual seja, o de guardião de um processo democrático que abre espaço para a participação popular.

Parece que o problema nessa proposta, todavia, é a ausência de canais formais que liguem a formação da opinião e da vontade na esfera pública informal à esfera pública parlamentar. $O$ filósofo alemão deixa claro que delineou seu modelo de política deliberativa especificamente para a formação do direito legítimo. Ele não quer que esse sistema se expanda para outros setores do governo sob pena de aproximar seu próprio modelo do republicano, o qual ele considera inadequado exatamente por exigir dos cidadãos um envolvimento constante com todas as atividades do governo, o que inviabilizaria, em seu entendimento, o exercício da cidadania nas sociedades contemporâneas.

Assim, o cidadão pode ter participação na criação do direito, mas não deve envolver-se com nenhuma tarefa de governo. Contudo, ao não criar canais formais de ligação entre a esfera pública informal e a esfera pública parlamentar, Habermas acaba deixando os indivíduos à mercê da vontade parlamentar. Ou seja, ainda que as diretrizes estabelecidas pelo Princípio do Discurso e pelo Princípio da Democracia sejam observadas na esfera pública parlamentar, não há nada que assegure que as reivindicações oriundas da esfera pública informal serão inseridas na agenda parlamentar. ${ }^{14}$ Nesse sentido, a própria criação do direito legitimo fica comprometida e, assim como a tentativa de conciliação entre autonomia privada e pública.

Essa mesma falha pode ser visualizada nas teorias de Waldron e de Bellamy. Esses autores apresentam uma concepção majoritária de democracia e recusam o controle de constitucionalidade em sentido forte, seja no que diz respeito aos direitos fundamentais, seja no que diz respeito aos procedimentos democráticos. Ambos apostam no fortalecimento das práticas democráticas e da cultura política como meio de proteção de direitos e das práticas democráticas. Eles analisam a tensão entre constituição e democracia de uma forma distinta dos demais autores aqui estudados: eles não buscam conciliar direitos fundamentais e o princípio da soberania popular, ao contrário, assumem a tensão e entendem ser fundamental posicionar-se a favor de um dos ideais, declarando-se favoráveis à democracia, isto é, ao princípio da soberania popular. Em outras palavras, eles aceitam que a tensão entre direitos

${ }^{14}$ Nesse sentido é a crítica de Bellamy a Habermas. Cf. BELLAMY, 2007, p. 128/129. 
fundamentais e o princípio da soberania popular é inerente à democracia constitucional e buscam acomodá-la politicamente.

Não há em seus textos, todavia, nenhuma proposta clara de remodelar o espaço da política e das práticas democráticas, permitindo aos cidadãos maior controle sobre seus representantes e interferência na tomada de decisões políticas. Para avaliar os limites dessa proposta, que pode ser aqui chamada de supremacia legislativa, podem ser invocados os mesmos parâmetros utilizados por Waldron para avaliar a tese do pré-compromisso constitucional. Como exposto, foram duas as objeções apresentadas: a primeira abordou o problema do desacordo político e, a segunda, o problema da ausência de julgamento independente (do povo).

Por um lado, uma democracia que abrace a proposta de supremacia legislativa pode dar conta de lidar com os problemas de desacordos a respeito da interpretação e ponderação de direitos, principalmente porque é capaz de abarcar e acomodar as mudanças sociais, permitindo que os desacordos políticos sejam avaliados e reconsiderados por meio do próprio processo político levado a cabo por representantes eleitos pelo povo. Por outro lado, a supremacia legislativa não se sai melhor do que a supremacia judicial quando se trata de avaliar o problema da ausência de julgamento independente. Esse problema consiste em que, ainda que as instruções (normas constitucionais) sejam bastante precisas, elas terão que ser interpretadas e a interpretação implica um julgamento externo e distinto da vontade do agente que concedeu as instruções. Isso, no entendimento de Waldron, compromete o julgamento de quem deu a ordem (a constituição) e torna o pré-compromisso incompatível com o autogoverno popular.

Aqui podem ser apontados dois problemas relacionados à objeção de Waldron quanto à ausência de julgamento independente. O primeiro é que, se esta crítica for levada às últimas consequências, para se evitar o problema do julgamento externo seria necessário implementar a sugestão de Jefferson de mudança constitucional a cada dezenove anos para que, desse modo, cada geração pudesse governar a si mesma e não ficar submetida às leis de seus antepassados. Não parece que seja esta a questão nem a intenção de Waldron ao levantar essa objeção. Quando se tem em mente a ponderação de princípios em uma situação de desacordo político, na maioria das vezes trata-se apenas de saber quem poderá fazer a sua interpretação à luz dos princípios constitucionais e não de instituir uma nova constituição. O segundo problema é que, quando Waldron considera o julgamento externo incompatível com o autogoverno, ele dirige esta objeção à atuação do poder judiciário. Contudo, é possível usá-la nos mesmos termos para o poder legislativo sem controle e, mais especificamente, sem controle popular. Se o povo não tem meios de exercer um efetivo controle sobre seus representantes, do mesmo modo, ainda que o julgamento dos princípios constitucionais seja feito dentro do legislativo representativo, ele continua sendo um julgamento externo (cf. KIS, 2009, p. 570-594). 
$\mathrm{Na}$ proposta de Waldron, não está claro como o poder legislativo deve ser controlado. Bellamy é um pouco mais propositivo do que Waldron ao sustentar que a teoria da separação dos poderes seja tomada como uma teoria do equilíbrio entre os poderes, cujo controle mútuo realizar-se-ia de forma horizontal e a partir da concorrência ou vigilância mútua entre cada um dos poderes.

De todo modo, de formas distintas, Habermas, Waldron e Bellamy manifestam uma forte preocupação com a definição do espaço da política, enfatizando que as decisões e deliberações a respeito de temas relevantes devem ocorrer em esferas representativas, notadamente o poder legislativo, e não dentro de instituições cujos membros não são politicamente responsáveis perante os cidadãos, como, por exemplo, o poder judiciário. Como anteriormente mencionado, considera-se que falta a essas propostas, contudo, um meio de vincular a opinião pública oriunda da esfera pública à agenda parlamentar e às decisões públicas institucionais tomadas por parlamentos e até mesmo por governos. No âmbito das teorias da democracia há propostas neste sentido. ${ }^{15}$

Em uma época em que muito se tem discutido a respeito das crises da democracia, principalmente da democracia representativa, uma avaliação crítica das propostas substancialista e procedimentalista contribui para trazer à luz alguns pontos críticos da relação entre os poderes e também chama a atenção para as consequências negativas que podem advir, para as práticas democráticas, quando o poder judiciário passa a exercer atribuições inerentemente políticas como, por exemplo, a transferência de responsabilidades do poder legislativo para o poder judiciário e o afastamento da possibilidade de interferência dos cidadãos em decisões de extrema relevância. Estudos empíricos comprovam que depois da segunda metade do século XX praticamente todas as sociedades democráticas ocidentais implementaram uma organização político-jurídica na qual o poder judiciário, notadamente os tribunais constitucionais, assume a atribuição de realizar o controle de constitucionalidade das leis. Tais pesquisas mostram que muitos temas genuinamente políticos (por exemplo, decisões sobre processos eleitorais, prerrogativas do poder executivo na área do planejamento macroeconômico ou de questões de segurança nacional, corroboração de mudança de regime, questões relacionadas à justiça de transição ou restaurativa, definição de critérios para a aquisição da cidadania, entre outros) passam a ser decididos dentro de tribunais constitucionais (cf. HIRSCHL, 2012, p. 140-156). Também no contexto jurídico-político brasileiro se verifica

\footnotetext{
${ }^{15}$ A esse respeito, ver, por exemplo, a proposta de Nadia Urbinati no livro Representative Democracy. Principles and Genealogy. (URBINATI, 2006). A autora retoma das teorias da democracia modernas, notadamente das obras de Thomas Paine e de Condorcet, um modelo de democracia representativa que concilia representação e participação, multiplicando os locais e os meios de tomada de decisão e de deliberação por meio de canais institucionais formais.
} 
a transferência de questões eminentemente políticas para o Supremo Tribunal Federal. É o caso, por exemplo, de questões polêmicas como o aborto de fetos anencéfalos, a pesquisa com células-tronco e, recentemente, o financiamento empresarial de campanhas eleitorais.

Como apontado por Waldron, frequentemente os problemas da democracia representativa levam a uma transferência de confiança dos cidadãos do legislativo representativo para o poder judiciário e, analisados os casos da realidade brasileira acima citados, talvez seja possível concordar com Dworkin que decisões melhores e mais justas talvez não tivessem sido tomadas dentro do legislativo representativo. Contudo, retornando às metáforas utilizadas pelos defensores do modelo do pré-compromisso, especialmente àquela apresentada por Hayek que pensa a constituição como um mecanismo que permite o "apelo do povo bêbado ao povo sóbrio", é importante ressaltar que a construção de uma cultura política democrática demanda dos cidadãos um esforço pela manutenção de sua sobriedade, de modo que eles se tornem os fiscais de instituições que podem, elas próprias, a qualquer momento se encontrar na situação de embriaguez. Nesse sentido, pode-se considerar que teorias que retiram a responsabilidade do povo na tomada de decisões coletivas acabam por incentivar a sua embriaguez.

\section{Referências}

BELLAMY, Richard. Political Constitutionalism: A republican defense of the constitutionality of democracy. New York: Cambridge University Press, 2007.

DWORKIN, Ronald. Is Democracy Possible Here? New Jersey: Princeton University Press, 2006a.

Press, 2011.

. Justice for Hedgehogs. Cambridge/Massachussets: Harvard University

- O Direito da Liberdade: a leitura moral da Constituição norte-americana.

Tradução de Marcelo Brandão Cipolla. São Paulo: Martins Fontes, 2006b.

O Império do Direito. Tradução de Jefferson Luiz Camargo. São Paulo: Martins Fontes, 2003.

ELSTER, Jon. Ulises $y$ las Sirenas: estudios sobre la racionalidad e irracionalidad. Tradución de Juan José Utrilla, Fondo de Cultura Económica: México, 1989, p.159. 
ELY, John Hart. Democracia y Desconfianza: una teoría del control constitucional. Traductora Madaglena Holguín.Santafé de Bogotá: Siglo del Hombre Editores, 1997.

HABERMAS, Jürgen. Direito e Democracia: entre facticidade e validade.Volume I e II. Tradução de Flávio Beno Sieveneichler, Rio de Janeiro: Tempo Brasileiro, 1997.

HAYEK, F.A. The Constitution of Liberty: the definitive edition. Edited by Ronald Hamowy, Chicago: Chicago University Press, 2011.

HIRSCHL, Ran. O novo constitucionalismo e a judicialização da política. In: Luiz Moreira (Org). Judicialização da Política. São Paulo: 22 Editorial, 2012, pp. 131-167.

HOLMES, Stephen. Precommitment and the Paradox of Democracy. In: J. Elster/ R. Slagstad (Orgs.), Contitutionalism and Democracy.Cambridge: Cambridge University Press, 1988.

JEFFERSON, Thomas. The Portable Thomas Jefferson. Edited by Merril D. Peterson, Penguin Books, 1977.

KIS, János. Constitutional Precommitment Revisited. In: Journal of Social Philosophy, Vol. 40 No. 4, 2009, 570-594.

MADISON, James. From James Madison to Thomas Jefferson, 4 February 1790. Disponível em: < http://founders.archives.gov/documents/Madison/01-1302-0020> Acesso em 16 set. 2015.

POST, Robert. Constitutional Domains: Democracy, Community, Management. Cambridge/Massachussetts: Harvard University Press, 1995.

TRIBE, Laurence H. The Puzzling Persistence of Process-Based Constitution Theories. In: Yale Law Journal, v. 89, 1979/1980, pp.1063-1080.

URBINATI, Nadia. Representative Democracy. Principles and Genealogy. Chicago: Chicago University Press, 2006.

WALDRON, Jeremy. A right-based critique of constitutional rights. Oxford Journal of Legal Studies.Vol. 13, N 1, 1993, pp. 18-51.

. Precommitment and Disagreement. In: L. Alexander, (org.). Constitutionalism. Philosophical Foundations. Cambridge: Cambridge University Press, 1998, pp. 271-299. 
. Law and Disagreement. New York: Oxford University Press, 1999.

. The Core of the Case Against Judicial Review. The Yale Law Journal, 115, 2006, pp. 1346-1406.

- Constitutionalism - A Skeptical View. In: T. Christiano/ J. Christman (orgs.). Contemporary Debates on Political Philosophy. Malden, Massachussetts: Blackwell Publishing, 2009, pp. 267-282.

E-mail: crisforoni@yahoo.com.br

Recebido: Dezembro/2015

Aprovado: Agosto/2016 